HEI Working Paper No: 07/2002

\title{
Bank Performance in Transition Economies
}

\author{
Steven Fries \\ European Bank for Reconstruction and Development (EBRD) \\ Damien Neven \\ Graduate Institute of International Studies, Geneva and CEPR \\ Paul Seabright \\ Université de Toulouse I and CEPR
}

\begin{abstract}
This paper examines the performance of 515 banks in 16 transition economies for the years $1994-99$ based on their public financial accounts. We first examine lending behaviour and probability distribution of bank profitability to determine whether these banks exhibit behaviour and performance associated with excessive risk-taking. While we do not find evidence of excessive risk taking on average where there is significant progress in banking and related enterprise reforms, there may be a minority of poorly capitalised banks that do take excessive risks, particularly where progress in reform is less advanced. The paper then estimates cost and revenue functions based on a model of banks as multiproduct firms. The results indicate that banks' performance differs significantly depending on the reform environment, as well as the competitive conditions, in which they operate. Banks with high market shares have higher costs and achieve lower margins on their loan and deposit activities. Where there has been significant progress in banking and related enterprise reforms, banks are making comfortable margins on loans and appear to be offering competitive margins on deposits, though they are still achieving overall negative returns on equity. By contrast, when substantial reforms have not been undertaken, banks have been sustaining high negative returns on loans, largely at the expense of depositors; in effect they have been able to appropriate much of the tax that inflation levies on nominal deposits, and have been using this revenue to prop up their weak loan portfolios. Overall interest margins are declining over time but are substantially higher in low reform environments. The results indicate that an appropriate policy and regulatory framework may be a necessary condition for significant progress to be made.
\end{abstract}

(C) The Authors.

All rights reserved. No part of this paper may be reproduced without the permission of the authors. 


\title{
Bank performance in transition economies
}

\author{
by \\ Steven Fries (EBRD) \\ Damien Neven (Graduate Institute of International Studies, \\ University of Geneva and CEPR), \\ Paul Seabright (Université de Toulouse I and CEPR)
}

September 2002

\begin{abstract}
This paper examines the performance of 515 banks in 16 transition economies for the years 1994 - 99 based on their public financial accounts. We first examine lending behaviour and probability distribution of bank profitability to determine whether these banks exhibit behaviour and performance associated with excessive risk-taking. While we do not find evidence of excessive risk taking on average where there is significant progress in banking and related enterprise reforms, there may be a minority of poorly capitalised banks that do take excessive risks, particularly where progress in reform is less advanced. The paper then estimates cost and revenue functions based on a model of banks as multi-product firms. The results indicate that banks' performance differs significantly depending on the reform environment, as well as the competitive conditions, in which they operate. Banks with high market shares have higher costs and achieve lower margins on their loan and deposit activities. Where there has been significant progress in banking and related enterprise reforms, banks are making comfortable margins on loans and appear to be offering competitive margins on deposits, though they are still achieving overall negative returns on equity. By contrast, when substantial reforms have not been undertaken, banks have been sustaining high negative returns on loans, largely at the expense of depositors; in effect they have been able to appropriate much of the tax that inflation levies on nominal deposits, and have been using this revenue to prop up their weak loan portfolios. Overall interest margins are declining over time but are substantially higher in low reform environments. The results indicate that an appropriate policy and regulatory framework may be a necessary condition for significant progress to be made.
\end{abstract}

JEL codes: G2, L1, L8, P2

Keywords: banking, cost functions, revenue functions, transition. 


\section{Introduction 1}

This paper analyses the performance of banks in a sample of transition economies, using a novel econometric approach to modelling banks as multi-product firms. The objective of the paper is gain insights with respect to the reform of the banking system in transition economies and in particular to understand why successful banking system reform is taking so long.

The development of a financially sound, market-oriented banking system is often thought to be fundamental to a successful transition. Arguably, it is vital both to macroeconomic stability and to favourable long-term growth prospects. Yet, as Berglöf \& Bolton (2001) and Fries \& Taci (2001) have documented, bank intermediation in transition economies remains stunted after a decade or more of reform, particularly where progress in banking reforms is limited. The profitability of the banking system also remains unimpressive, once the effect of inflation on real profitability is taken into account. The ratio of net profit before taxes to total assets has averaged about $1.2 \%$ in the large sample of banks from transition economies, which is the focus of this paper. This figure appears to compare favourably with the typical performance of banks in the OECD where returns averaged about $0.7 \%$ of total assets, in the period 1993 to 1995 . However, when the effect of inflation on the real value of bank equity is taken into account, we find that returns in transition economies dwindle to a mere $0.02 \%$. This paper attempts to shed some light on the developments achieved by banks in transition and their performance (or lack thereof).

The weak performance of banks in transition economies is in many ways unsurprising. Like industrial firms, socialist banks were themselves enterprises that were often badly in need of restructuring at the outset of transition. Until then, banks had been used mainly to channel funds, providing credits to state enterprises for investment projects approved under central planning. The allocation of finance was not determined by the opportunity cost of funds and the expected ability to repay; or at least, if such considerations ever

\footnotetext{
${ }^{1}$ The valuable research assistance of Nadia Aleshina, Andrij Halushka, Charles Ng and Colin Rowat is gratefully acknowledged. We are also grateful to Erik Berglöf, Wendy Carlin, Christa Hainz, Mark Schaffer and Claudia Senik-Leygonie for very helpful comments and suggestions. The usual disclaimer applies.
} 
influenced investment decisions, it was at the planning level and not at the level of the banking system. As a consequence, banks have had to restructure their own activities and learn from scratch much of the trade of their counterparts in market economies.

Particular features of the banking industry also make restructuring particularly hard to achieve. The conditions that are most conducive to the restructuring of industrial enterprises (difficult as this is) are effective competition in the product market, effective mechanisms of corporate control and the imposition of hard budget constraints (see, for example, Carlin, Fries, Schaffer and Seabright (2001)). But these are even less likely to obtain in the case of banks than of most ordinary firms. Consider product market competition. When commercial and central banking functions were separated early in the transition, the "monobank" inherited from central planning was almost invariably split into a very small number of independent entities. Moreover, the process of entry into the banking sector was often poorly regulated, with many newly established private banks lacking the necessary capital and skills to compete effectively with the dominant stateowned and privatised banks.

It is with hard budget constraints, however, that the main difficulty arises. Given that banks are prone to runs and that bank failures can precipitate a financial crisis, banks almost invariably benefit from some form of state guarantee (either through an implicit bailout commitment by the central bank or explicit deposit insurance). A simple hard budget constraint is not appropriate for banks even in mature market economies, so it is likely that bank restructuring will be even more difficult in transition than the restructuring of enterprises for which uncompromising bankruptcy rules make more sense.

In this paper, we consider a sample of 515 banks from 16 countries over the years 199499. Of the total number of banks, 10 are in Belarus, 26 in Bulgaria, 45 in Croatia, 30 in the Czech Republic, 14 in Estonia, 12 in the FYR Macedonia, 36 in Hungary, 22 in Kazakhstan, 28 in Latvia, 13 in Lithuania, 52 in Poland, 29 in Romania, 118 in Russia, 21 in the Slovak Republic, 29 in Slovenia, and 30 in Ukraine. The data for individual banks are annual and they include information from income statements and balance sheets and 
on bank ownership. The banks covered in this study account for the vast majority of banking operations in their respective countries.

The primary source of data on the banks' balance sheets, income statements and ownership is the BankScope database produced by the Bureau van Dijk, which includes data on 10,227 banks world-wide. The database is updated monthly and latest issue of the BankScope database used in this study was March 2001. The BankScope data were supplemented with the data and information from annual reports of the banks and from EBRD staff research on bank ownership. The central banks of the countries provided aggregate data on their banking systems for use in calculating market shares in deposit taking and lending activities. The sources of the macroeconomic data on the relevant countries were the IMF's International Financial Statistics.

We estimate an econometric model both of bank revenues (adjusted for inflation) and a standard cost function. The revenue function identifies banks' return on equity and the source of bank revenues - in particular the relative profitability of loan-making and deposit-taking activity - and allows us to investigate a number of determinants of firms margins, including corporate control variables and measures of market power. The cost function captures variation in productive efficiency across banks and over time.

One concern with evaluating performance on the basis of banks' accounts, however, is that accounting profits may not accurately reflect economic profits, particularly regarding the risk of bank assets and their valuation. This is partly because of variations in accounting conventions across countries, though the fixed effects methodology we employ in this paper is intended to minimise distortions arising from this source as far as reasonably possible. More worryingly, current accounting profits may well come at the expense of future profits when banks engage in excessive risk taking. Before undertaking the econometric investigation we therefore consider in section 2 the extent to which banks may have taken excessive risks by examining the lending behaviour and profitability of banks in different reform environments. While we do not find evidence of excessive risk taking where there is significant progress in banking and related enterprise reforms, there may be a minority of poorly capitalised banks that do take excessive risks, particularly where there is inadequate institutional development. 
Our econometric findings in section 3 indicate that banks' performance differs significantly depending on the environment in which they operate. Where there has been significant progress in banking and related enterprise reforms in the areas of bankruptcy and corporate governance, new entrants have had significantly lower costs, as have firms in more competitive markets. Banks in a favourable reform environment also obtain low margins on deposits and relatively high margins on loans, though they have nevertheless been achieving overall negative returns on equity. By contrast, when substantial banking and enterprise reforms have not been undertaken, new entrants have been unable to achieve significant cost savings. Average returns on loans have also been strongly negative. Although returns on equity are unimpressive, it is principally depositors rather than shareholders who have been bearing the cost, since they have been receiving very poor real returns to their savings. The outlook is not entirely bleak - returns on loans at the margin, for instance, are greater than average returns, indicating that banks which have managed to grow their loan portfolio over time have been doing substantially better than others. Nevertheless, the overall record is poor: in these low reform environments, much of the tax that inflation levies on nominal deposits has simply disappeared down the drain of poor bank loan management and cost control.

\section{Excessive risk taking?}

In general, what provides banks with an incentive not to take excessive risk is the prospect that in case of failure they will lose the rents they obtain from operating as financial intermediaries and the capital that they already have. These rents typically arise from institutional barriers to entry, such as banking licences, which are valuable assets that established banks will seek to protect. The capital is either paid in by shareholders or accumulated from profits after taxes and dividends. From the point of view of the managers of a bank, therefore, risk taking above normal prudent levels has two opposite consequences. On the one hand, it enhances the expected profits of the bank and its shareholders at the expense of the implicit or explicit insurance mechanism. On the other hand, it enhances the probability of losing the banking licence. It is intuitively clear that when the value of the banking licence is small, the first effect will dominate the second. When it is large, banks will seek to protect it by reducing risk taking.

Faced with sudden difficulties, the optimal strategy of banks will differ according to the 
value of their licence (see Marcus (1984)). If it exceeds some threshold value, banks will attempt to re-capitalise. This will reduce the probability of failure and protect the licence. But if the value of the licence lies below the threshold, banks will reduce their capital base thereby attempting to extract the most from the insurance mechanism. This strategy is often referred to as "gambling for resurrection". In addition to the value of the banking license, the value of the threshold also depends on the initial capital base of the institution. The stronger the capital base and the larger is the value of the banking licence, the lower is the probability that banks will gamble for resurrection. Faced with a common negative shock, the population of banks will divide into two groups. Banks with a strong capital base and/or a valuable banking licence may decide to strengthen their capital base while others decide to gamble. This choice can also be constrained by banking regulation and supervision, depending in part on the extent of institutional development.

The circumstances of transition economies are also potentially favourable to the emergence of excessive risk taking. First, the initial shock associated with the liberalisation of prices that had affected the underlying value of bank assets was both large and unpredictable. It has proved difficult to judge the appropriate degree of recapitalisation, which has taken place in all countries (albeit in different ways), and it is unclear whether the improvement in the capital base was always sufficient to avoid incentives for excessive risk taking. Second, at least some banks have been affected by severe additional shocks. To the extent that lack of progress in enterprise reform to complement the privatisation of large-scale enterprises that has been observed in at least some countries was not anticipated, the value of the banks' assets has been further undermined. These subsequent shocks may have triggered excessive risk-taking for some banks. Casual evidence of bank failures as late as 1997 in Hungary, not to mention the Russian banking crisis of 1998, certainly confirm that the situation of some banks has remained precarious well into the process of transition.

Whether a particular bank does engage in "gambling for resurrection" can in principle be inferred from its lending policy and the evolution of its capital base. The total volume of loans should grow with a shift towards more speculative assets, the proportion of problem loans should increase, provisions should fall and the capital base should shrink. There is indeed some ex post evidence suggesting that relatively high loan growth is a significant leading indicator of banking crises (see, for example, Kaminsky and Reinhart (1999)). In 
terms of profitability, one would expect that, on average, returns will also fall (indeed, if they do not, the strategy is no longer an instance of socially undesirable moral hazard). However, returns may not fall immediately: it is quite possible for "gambling for resurrection" to involve high present returns at the expense of a deterioration in the quality of the loan portfolio that translates into lower profitability only in future years. All of these variables can in principle be observed, but it is hard to establish a proper benchmark against which their evolution can be assessed. For instance, it may be difficult to decide at what stage a particular rate of loan growth can be considered excessive.

Hence, rather than considering individual banks, we rather try to detect the presence of gambling for resurrection from the behaviour and performance of the population of banks. In particular, we will examine whether the population of banks divides in separate groups with different lending behaviour and profitability performance. The benchmark against which the loan policy and profitability of gambling banks is assessed in this approach is thus the behaviour and performance observed for an alternative set of banks. Importantly, this approach assumes that there are banks that do pursue a policy prudent lending and recapitalisation. We assume that this behaviour is more likely to be observed where the institutional framework for banking and bank lending to private borrowers is more developed. It appeals to the theoretical arguments for a threshold value of bank capital that divides the population of banks into two distinct groups pursuing different strategies and that bank capital requirements are more likely to constrain effectively lending decisions where the institutional framework is relatively well developed.

In what follows, we consider two measures of bank behaviour and performance. First, we examine whether loan growth is positively or negatively associated with the capital base of banks. A positive association between these variables across banks would be consistent with prudent lending on the basis of adequate bank capital and favourable profitability dynamics, given the negative relation between bank capital and the incentive to "gamble for resurrection". A zero or negative association would suggest that low levels of bank capital do not constrain banking lending, which points to the presence of "gambling for resurrection", at least by those banks with low levels of bank capital and high real loan growth. Second, we consider the distribution of returns across banks and attempt to detect differences in the overall balance between expected returns and risks and in their evolution over time. This includes the possible emergence over time of a bi-modal 
distribution of profitability that would be characteristic of population of banks that is separating into two groups of "gambling" and "sound" banks.

We examine each measure for two samples of banks. One sample includes observations for banks in those countries and years in which a "high" reform state is achieved. This state is defined using indices compiled by the EBRD for both banking reform and related enterprise reforms in the areas of bankruptcy and corporate governance. A high reform state is characterised by a country having achieved an index score in the top half of the scale for both banking and enterprise reforms. The other sample includes observations for banks in those countries and years in which only a "low" reform state is achieved (defined as not the high state). This partitioning of the entire sample results in two broadly equal sub-samples in terms of numbers of observations.

In order to investigate the association between loan policy and the quality of balance sheets, Charts 1 and 2 plots loan growth (adjusted for inflation) against the ratio of equity to total assets lagged one year. The charts show the association between real growth in outstanding loans and capital-asset ratios for the "high" and "low" reform states, respectively. A fitted non-linear regression curve suggests that high rates of loan growth are associated with high ratios of equity to total assets in the high-reform state and that there is no significant association between loan growth and bank capital in the low-reform state. In fact, in a multivariate regression analysis of the determinants of real loan growth for similar samples of banks, Fries and Taci (2001) find a statistically significant and positive association between loan growth and bank capitalisation in the high-reform state, but no such relationship in the low-reform state. This result suggests that low levels of bank capital tend to constrain the real expansion of loans where banking and related institutions are more developed, but that there may be a greater incidence of "gambling for resurrection" in the low reform state by banks with low capital-asset ratios.

$<<$ Insert Charts 1 and 2 near here $>>$

We use a standard non-parametric procedure (essentially a smoothed histogram) to plot the density of profits adjusted for inflation expressed as a per cent of total assets. Chart 3 shows the density functions for the samples of banks in the high- and low-reform states. The modal value for the inflation-adjusted rate of return on assets in the high-reform state 
is above that in the low-reform state $(0.62 \%$ versus $0.40 \%)$ and the dispersion of the distribution in the low-reform state is clearly greater than that in the high-reform state. The variance of the profitability distribution in low-reform state exceeds by a factor of 3 that of the profitability distribution in the high-reform state. This result suggests that banks in the low-reform state take on greater risks than do those in the high-reform state, which is consistent with the evidence on real loan growth relative to bank capital pointing to greater risking by banks in the low-reform state.

$<<$ Insert Chart 3 near here $>>$

Charts 4 and 5 show the evolution of the profitability densities over time in the highreform and low-reform states, respectively. In the high-reform state, the modal point of the density function shifts over time, but the dispersion of the distribution remains relatively stable, except for 1998. In this year, the distribution has a relatively fat lower tail, with a significant number of loss-making banks in Hungary and the Czech Republic. In the low-reform state, the modal point of the density functions shifts over time, but the dispersion again remains relatively stable except for 1998 and 1999. In 1998, the distribution has a relatively fat lower tail and in 1999 it has relatively slim tails. This reflects the significant losses incurred by Russian, Latvian and Ukrainian and banks in 1998 in the aftermath of the Russian financial crisis and the significant reduction in number of loss-making banks in the sample in 1999. However, there is no direct evidence of the emergence of a bi-modal distribution of bank profitability in either the high- or low-reform state. The absence of a bi-modal distribution is still consistent with the possibility that a minority of banks is engaging in excessive risk taking in pursuit of shortterm profits.

$<<$ Insert Charts 4 and 5 near here $>>$

There are several reasons, however, for interpreting this evidence with caution. First, as with the accounting valuation of loans, the ratio of equity to total assets is a lagging indicator of a bank's financial strength. The accounting measure of equity can overstate the true strength of a bank when non-performing loans have not been classified and provisioned against. Nevertheless, measured equity is somewhat less sensitive to misreporting than loan values are because it includes the equity contributions of shareholders 
as well as the cumulation of past reported profits and losses. Second, the results indicate the presence of a substantial minority of banks whose loan portfolios are growing on an inadequate foundation of shareholder equity. The behaviour of this minority of banks can give cause for concern even if it is not characteristic of the sample as a whole. Third, banks can engage in forms of risk taking other than rapid loan growth. The Russian banking crisis noted above arose not only from a proliferation of non-performing loans, but also from large open foreign exchange positions assumed through off-balance sheet transactions.

We now turn to our main empirical analysis, namely the estimation of revenue and cost functions for individual banks.

\section{An econometric model of banks' revenues and costs}

In this section, we derive a simple econometric model, which can shed some light on the productive efficiency and the source of revenues for banks. Following Freixas and Rochet (1998), we recognise that banks manage both their liabilities, by attracting deposits, and their assets by providing loans and investing into securities, with the constraint that total assets should be equal to total liabilities, including their own equity capital. As far as we are aware, this is the first time such an approach to the multi-product nature of banking has been implemented econometrically2. To the extent that the total volume of deposits obtained from non-financial institutions does not match the volume of their loans, banks also have the opportunity of borrowing, or lending, in the inter-bank market.

The profit function of a representative bank then includes the returns it obtains from lending activities, the returns it obtains from non-loan assets, the interest it pays on deposits, the interest cost of its net position on the inter-bank market, as well as the (management) cost of undertaking its activities. Let $D_{i}, L_{i}$ and $N_{i}$ denote deposits, loans and securities investment of a representative bank $i, C\left(D_{i}, L_{i}, N_{i}, W_{i}\right)$ refer to management costs ( $W_{i}$, is a set of factor prices), $R$ be the inter-bank rate, and $r^{l}, r^{d}$ and $r^{n}$ respectively

\footnotetext{
${ }^{2}$ This approach also avoids fruitless debates about whether deposits are an input to the production of loans or loans an input to the production of deposits. Banks produce both deposits and loans, subject to a balance sheet constraint linking the quantity of one to the quantity of the other.
} 
be the interest obtained on loans, the interest paid on deposit and the return obtained from non-loan assets. Finally, $E_{i}$ is the equity capital of the bank. The profit function can then be written as:

$$
\pi_{i}=r_{i}^{l} L_{i}-r_{i}^{d} D_{i}+r_{i}^{n} N_{i}-R \cdot\left(L_{i}+N_{i}-E_{i}-D_{i}\right)-C\left(D_{i}, N_{i}, L_{i}, W_{i}\right),
$$

where $\left(L_{i}+N_{i}-E_{i}-D_{i}\right)$ represent the net debtor position of the bank in the inter-bank market. The profit function of the representative bank can then be rewritten as follows:

$$
\pi_{i}=\left(r_{i}^{l}-R\right) L_{i}+\left(R-r_{i}^{d}\right) D_{i}+\left(r_{i}^{n}-R\right) N_{i}+R E_{i}-C\left(D_{i}, N_{i}, L_{i}, W_{i}\right) .
$$

In order to evaluate the sources of banks profit, we will consider costs and revenues separately. With respect to productive efficiency, and given that we have data on management costs, we will estimate a cost function directly.

With respect to revenues, denoted $R E V_{i}$, they can be written as:

$$
R E V_{i}=\left(r_{i}^{l}-R\right) L_{i}+\left(R-r_{i}^{d}\right) D_{i}+\left(r_{i}^{n}-R\right) N_{i}+R E_{i} .
$$

Revenues, loans, deposits, equity and non-loan assets are observed and this equation can be directly estimated. The parameters provide estimates of the average margins that banks have earned on loans, deposits and non-loan assets, and also an estimate of the inter-bank rate, or more generally the opportunity cost of banks' own funds.

If the returns on non-loan assets and the inter-bank rate can be seen as exogenous for the banks, the rates that they charge on loans and deposits determine the respective margins or "prices". The question then arises whether the variance of margins across banks and over time can be further exploited. Both the price charged by a bank at particular point in time and the quantity that it sells (either loans or deposits) are jointly determined as a result of the interaction between each firm's supply curve and the demand that they face. Observed prices and quantities should be seen as an equilibrium outcome of oligopolistic 
competition among banks 3 . These equilibrium prices and quantities can also be expressed in terms of exogenous parameters (like the number of banks and the demand and cost parameters).

The estimated coefficients in front of loans and deposits can therefore be seen as an equilibrium price, and the structure of these equilibrium prices across banks and over time can be further explored. In particular, the effects of exogenous variables on the equilibrium can be directly estimated, by specifying an equilibrium price function. In what follows, we will thus specify a model of oligopolistic competition among banks and derive equilibrium prices as a function of the underlying parameters. That is, we will explicitly derive equilibrium prices in the context of a structural model, obtain a reduced form for individual equilibrium prices and estimate the parameters of this reduced form.

It is worth emphasising that this estimation does not allow for a direct identification of market power (or the estimation of supply functions). This requires the estimation of a structural model where demand and supply functions are jointly estimated, using observed prices and quantities (see, for instance, Bresnahan (1989) for an exposition of this approach and Ribon and Yosha (1999) or Neven and Röller (1999) for applications to banking). Nevertheless, the structure of equilibrium prices (and their decomposition into costs and margins) may give some indirect insight into the existence of market power as well as the influence of corporate control ${ }^{4}$.

Consider the loan market (the analysis can be applied mutatis mutandis to the deposit market). Assume that banks take the inter-bank market as given and that they define their loan policy independently of their strategy with respect to deposits. This will hold if the cost function is separable in the two outputs. Assume that marginal management costs are constant (linear marginal cost could also be accommodated without difficulty). The profit function of bank $\mathrm{i}$ in the loan market is then given by:

$$
\pi_{i}=\left(P_{i}-c_{i}\right) L_{i}
$$

\footnotetext{
${ }^{3}$ For a model emphasizing the importance of market power in transition banking, see Hainz (2002).

4 This approach is thus semi-structural and in this respect is similar to that of Panzar-Ross which has often been applied to the banking industry (see De Bandt and Davis (2000) for a recent example).
} 
where

$$
P_{i} \equiv r_{i}^{l}-R
$$

Assume further that each bank faces an inverse demand function of the type:

$$
P_{i}=a_{i}-L_{i}-\lambda L_{-i}
$$

where $L_{-i}$ denotes the total volume of loans sold by all other banks (in the same country and time period) and where $\lambda<1$. This demand specification (adapted from Shubik and Levitan (1980)) allows for product differentiation; banks may be able to differentiate their product in such a way that their demand curve is shifted out (the intercept $a_{i}$ increases). In addition, this specification allows for reduced substitution between a bank's products and those of competitors ( $\lambda$ falls). Such reduced substitution can be associated with product differentiation or market segmentation (induced for instance by a lack of competition). The characteristics of bank's products that determine such differentiation are not observed.

Faced with this demand specification, each bank will maximise profit by solving the following first order condition:

$$
a_{i}-2 L_{i}-\lambda L_{-i}-c_{i}=0 \text {. }
$$

Summing up the first-order conditions for all banks yields

$$
\sum_{i}\left(a_{i}-c_{i}\right)-2 L-\lambda(n-1) L=0,
$$

where $L$ denotes total loans provided by a banking system in a country. The volume of total loans in equilibrium is then given by

$$
L^{*}=\left[\sum_{i}\left(a_{i}-c_{i}\right)\right] /[2+\lambda(n-1)] .
$$


Combining this expression with the first order condition for each bank yields the equilibrium market share $\left(M S_{i}^{*}\right)$ and price $\left(P_{i}^{*}\right)$ :

$$
\begin{aligned}
& \left.\left.M S_{i}^{*}=[1 /(2-\lambda)]\right\}\left[\left(a_{i}-c_{i}\right) / \sum_{i}\left(a_{i}-c_{i}\right)\right][2+\lambda(n-1)-\lambda]\right\}, \text { and } \\
& \left.\left.P_{i}^{*}=\left[\left(a_{i}+c_{i}\right) / 2\right]-[\lambda /(2-\lambda)]\right\}\left[\sum_{i}\left(a_{i}-c_{i}\right) /[2-\lambda(n-1)]\right]-\left[\left(a_{i}-c_{i}\right) / 2\right]\right\} .
\end{aligned}
$$

The equilibrium loan market can then be expressed in terms of market share. From this expression it is possible to show that the derivative of the ith bank's equilibrium loan margin with respect to its share of the loan market is:

$$
\partial M_{i}^{*} / \partial M S_{i}^{*}=\sum_{i}\left(a_{i}-c_{i}\right)\left\{1+\left[c_{i}(\lambda-2) /\left[\left(c_{i}-a_{i}\right)(2+\lambda n)+\lambda \sum_{i}\left(a_{i}-c_{i}\right)\right]\right]\right\} .
$$

It is straightforward to show that this expression is positive for all values of the parameters for which market shares are positive. Therefore, an increased share of the loan market translates into a higher lending price or margin. More generally, equilibrium margins will be a function of market shares, of the parameters of demand and firm specific characteristics. Of particular interest will the sensitivity of prices to market shares. Taking the derivative of the last expression with respect to $\lambda$, it is easy to check that the sensitivity of prices to market shares is inversely related to $\lambda$ and directly to a high level of overall demand (for a given number of firms). In other words, if we observe that prices are sensitive to market shares, it will be a symptom of high market segmentation and/or insufficient entry. Of course, the high level of segmentation could be associated with genuine product differentiation but this is less likely in the context of transition economies.

\subsection{Empirical implementation}


For the cost function, we considered a standard translog function but subsequently dropped the second-order terms (none of which have proved at all significant in our preliminary estimations, and which add seriously to problems of multicollinearity). The cost of firm $i$ in country $k$ at time $t$ is specified as follows:

$$
\begin{aligned}
\ln C_{i k t}= & \sum_{j} \alpha_{j}^{c} C D_{j}+\beta^{c} \ln L_{i k t}+\chi^{c} \ln D_{i k t}+\delta^{c} \ln W_{k t}+\phi^{c} \ln r_{k t}+\varphi^{c} \text { PRIVATE }_{i k t}+ \\
& \gamma c \text { FOREIGNikt }+\eta c G R O W T H k t+\kappa c I N F L A k t+\mu c T+\varepsilon_{i k t}^{c},
\end{aligned}
$$

where we introduce country fixed effects ( $C D_{j}$ refer to country dummy variables), wages $\left(W_{k t}\right)$ and the real interest rate $\left(r_{k t}\right)$ as factor prices and a time trend $(T)$ in order to trace out potential productivity improvements in efficiency over time. We introduce bank characteristics to identify whether particular forms of corporate control are more effective. They include dummy variables to identify privatised banks ( $\left.P R I V A T E_{i k t}\right)$ and new entrants $\left(D E N O V O_{i k t}\right)$ and to indicate the presence of majority foreign ownership $\left(F O R E I G N_{i k t}\right)$. We introduce the three firm concentration index $\left(C R 3_{k t}\right)$ as a proxy for the number of banks in a country's banking system, to capture the possibility that market power is translated into high costs (through the "quiet life" - see $\mathrm{Ng} \&$ Seabright, 2001). We also introduce a number of variables that characterise the economic environments in which banks operate. They include the real rate of growth $\left(G R O W T H_{k t}\right)$ and the rate of inflation $\left(I N F L A_{k t}\right)$.

In the empirical implementation of revenue equation, we assume that banks face exogenous prices for investments in non-loan assets but compete for both deposits and loans. Following the above derivation, we write individual equilibrium prices as a function of market shares, parameters of demand and firm characteristics. More precisely, the equilibrium price of bank $i$ in the loan market $l$ in country $k$ at time $t$ is expressed as:

$$
P_{i k t}^{l}=\sum_{j} \alpha_{j}^{l} C D j+\beta l G R O W T H k t+\chi l I N F L A k t+\phi l C R 3 k t+
$$




$$
\varphi^{l} \text { PRIVATE }+\gamma^{l} \text { DENOVO } i k t+\eta^{l} \text { OOREIGN }_{i k t}+\kappa^{l} M S_{i k t}^{l}+\lambda^{l}\left(M S_{i k t}^{l}\right)^{2}+\varepsilon_{i k t}^{l} .
$$

That is, we allow for country fixed effects (where $C D_{j}$ are country dummy variables) and use real GDP growth $\left(G R O W T H_{k t}\right)$, inflation $\left(I N F L A_{k t}\right)$ and variables that shift demand. As bank characteristics, we include (as in the cost equation) dummies to identify privatised banks $\left(\right.$ PRIVATE $\left._{i k t}\right)$ and new entrants $\left(\right.$ DENOVO $\left._{i k t}\right)$ and to indicate the presence of majority foreign ownership ( FOREIGN $\left.N_{i k t}\right)$. The same specification is used for the equilibrium prices in the deposit market (simply substitute the superscript $d$ ). The error term is assumed to have the usual properties.

The equation that we estimate is therefore written as:

$$
R_{i k t}=P_{i k t}^{l}(.) L_{i k t}+P_{i k t}^{d}(.) D_{i k t}+\theta N_{i k t}+\rho E_{i k t}+\varepsilon_{i k t},
$$

where $\theta$ and $\rho$ can be interpreted respectively as the (exogenous) return that banks can obtain on non-loan assets and the inter-bank rate. Given that we introduce disturbances on both price equations, the overall error term can be written as:

$$
\varepsilon_{i k t}^{l} L_{i k t}+\varepsilon_{i k t}^{d} D_{i k t}+\varepsilon_{i k t} .
$$

To account for the induced heteroscedasticity, we estimate this equation with GLS, and because of the dependence of the presence of an error term in the coefficient on loans and that on deposits, we instrument both loans and deposits using their own lagged values (a Durbin-Wu-Hausman test indicates this is indeed appropriate in most of the estimations we report below). Similar considerations lead us to instrument market shares, since these are themselves measured by revenues.

All our value data are expressed in real US dollars. With respect to bank revenues, we also consider the effect of inflation on bank equity (which is not protected against inflation). Inflation adjusted bank revenues are therefore computed as real revenues less the erosion of bank equity. The latter is measured as the equity base in the previous year multiplied by the reciprocal of one plus the current inflation rate. 
We estimate the cost and revenue equations while allowing for bank specific effects. We estimate both fixed and random effects, but report only the random effects, since both the Haussman and Breusch-Pagan tests overwhelmingly reject the fixed-effects model in all specifications in favour of random effects. For the revenue equation estimates, where we instrument for loans and deposits, we use Baltagi's (1981) error-components 2-stage least squares (EC2SLS) estimator (see Baltagi, 1995, chapter 7).

We also estimate both equations separately for the entire samples and for two subsamples, which comprise respectively high and low reform countries. These sub-samples are determined from an indicator of banking reform which provides a ranking of progress in liberalisation and institutional reform of the banking sector, on a scale of 1 to $4+$. A score of 1 represents little change from a socialist banking system apart from the separation of the central bank and commercial banks, while a score of 2 means that a country has established internal currency convertibility and has liberalised significantly both interest rates and credit allocation. A score of 3 means that a country has achieved substantial progress in developing the capacity for effective prudential regulation and supervision, including procedures for the resolution of bank insolvencies, and in establishing hardened budget constraints on banks by eliminating preferential access to concessionary refinancing from the central bank. A score of 4+ represents a level of reform that approximates the institutional standards and norms of an industrialised market economy, as represented, for example, by the Basle Committee's Core Principles on Effective Banking Supervision and Regulation. The scoring assessments are by EBRD country economists (see EBRD (2000), Chapter 2).

We partition the panel data set using the EBRD transition indicators because in theory the behaviour and performance of banks is dependent on the nature of policies and institutions (see Lucas, 1976) and because there is significant empirical evidence from transition banking to this effect (see Fries and Taci, 2002). Since the EBRD transition indicators are ordinal measures of changes in policies and institutions that affect banking, we should in principle interact each value of the indicators separately with each of the explanatory variables. However, to obtain a more parsimonious expression, we simply partition the data set into two sub-samples (relatively high and low reform states) using the indicators and then examine whether bank behaviour and performance differs between 
the two sub-samples.

\subsection{Results}

Table 1 reports cost function estimates for the whole sample as well as the high and low reform sub-samples. Table 2 reports revenue function estimates for the high and low reform sub-samples. Let us first summarise the results for the high reform sub-sample. With respect to costs, we first observe that banks operate with increasing returns, with an elasticity of costs with respect to output well below unity. The very low elasticity of costs with respect to real wages $(0.097)$ suggests that banks facing higher wages over time have been able been able to substitute other factors for labour. This suggests that new, laboursaving technologies have spread easily in transition economies. Next, we find evidence that rents in the loan market may lead to productive inefficiency, with costs rising by 1.8 $\%$ for each percentage point increase in market share. New entrant banks have strikingly lower costs than others, though privatisation per se has no significant effect. Costs are also strongly negatively correlated with overall GDP growth.

As far as revenues are concerned, banks have been earning comfortable margins over their marginal cost of funds in the loan market, but margins are even negative (though insignificantly so) in the deposit market. Margins actually decrease with market shares, which corroborates the evidence from the cost function to suggest that market power makes for poor management rather than high profits (overall market concentration is insignificant in these equations and has been omitted from the reported specifications). Overall returns on equity are very poor (over $20 \%$ negative in real terms). Alternative corporate control structures do not seem to affect margins, with the exception of banks with majority foreign ownership, which have slightly lower margins (by less than a percentage point). Real deposit margins are also positively affected by inflation, whereas real loan margins are negatively affected. Such effects of inflation are commonly observed for banks in the EU (see for instance, Gual and Neven (1993)) and are usually attributed to the presence of transactions costs and hysteresis. Finally, revenues show a secular tendency to rise over time though so, unfortunately, do costs.

\footnotetext{
${ }^{5}$ High collinearity between deposit and loan market shares means we have not been able to distinguish between deposit and loan market power as such. We cite the measure that has the higher significance of the
} 
The situation in the low reform countries is rather different, particularly on the revenue side. As far as costs are concerned, new entrants do not have significantly lower costs, and the estimated lower costs of banks with majority foreign ownership are only weakly significant at conventional levels. Once again costs are negatively correlated with macroeconomic growth. However, the revenue side shows a strikingly different pattern from the high reform countries. There are large negative margins on loans ${ }^{6}$ (nearly 10\%) and very large margins on deposits. Margins are once again negatively affected by market share. It is striking that de novo and privatised banks obtain lower returns (by around 5 percentage points), and also those with a foreign majority stake, by an even wider margin. This is consistent with the view that incumbency is playing a major role, presumably through the initial stock of deposits. Returns on equity are insignificantly different from zero. This suggests that banks in low reform countries have been benefiting from seignorage revenue on deposits, and then using these rents to sustain their portfolios of weak loans.

Finally, in Table 3 we investigate the robustness of these findings (and particularly the difference between the high and low reform groups), by reporting estimates on a pooled sample. The first equation uses slope dummies to test the hypothesis that margins on deposits and loans, as well as returns to equity, are significantly different in the two subsamples. An F-test comfortably rejects the hypothesis of equality of coefficients in all cases, and the results are qualitatively identical to those reported in Table 2. The second equation interacts the equity and deposit variables directly with the measure of progress in banking reform that was used to construct the sub-samples, as well as interacting the loan variable with the measure of progress in enterprise reform. Returns on loans increase very significantly with progress in enterprise reform, as one might expect given that the majority of loans are those to enterprises ${ }^{7}$. Likewise, returns on deposits fall with progress in banking reform, which makes sense given that banking reform is likely to increase the degree of competition in the banking system and reduce the extent to which depositors are captive to the banks.

two on an equation-by-equation basis.

${ }^{6}$ The returns on loans that is estimated within groups may be larger than the estimate across groups. This is actually confirmed by the estimates of a fixed effect model (not reported). It would therefore appear that banks which have grown their loan portfolios have obtained higher (and possibly positive) returns than those suggested by the random effects estimates.

${ }^{7}$ It is intuitive that it should be enterprise reform that affects loan margins more than banking reform per se, but we also tested the interaction with banking reform, which is insignificant. 


\section{Conclusion}

This paper has examined the performance and profitability of 515 banks in 16 transition economies for the years 1994 - 99 based on their public financial accounts. We first examine lending behaviour and probability distribution of bank profitability to identify whether these banks exhibit behaviour and performance associated with excessive risktaking. Evidence of excessive risk taking would point the possibility that banks are trading off greater short-term accounting profits at the expense of higher risks, the costs of which may not be fully reflected in banks' accounts. While we do not find evidence of excessive risk taking where there is significant progress in banking and related enterprise reforms, there may be a minority of poorly capitalised banks that do take excessive risks, particularly where progress in reform is less advanced.

In the estimated cost and revenue functions of banks, we also find that banks' performance differs significantly depending on the reform environment, as well as the competitive conditions, in which they operate. Banks with high market shares have higher costs and achieve lower margins on deposits. Where there has been significant progress in banking and related enterprise reforms, banks are making comfortable margins on loans and appear to be offering competitive margins on deposits, though they are still achieving overall negative returns on equity. By contrast, when substantial reforms have not been undertaken, banks have been sustaining high negative returns on loans, largely at the expense of depositors; in effect they have been able to appropriate much of the tax that inflation levies on nominal deposits, and have been using this revenue to prop up their weak loan portfolios.

The outlook is not entirely bleak. Table 4 indicates that net interest margins, which are an indicator (albeit an imperfect one) of the effective cost of intermediation to the users of the banking system, have been falling over time, as well as being systematically lower in the high reform countries. The data do not allow us to tell to what extent these falling margins represent genuine reductions in anticipated margins as opposed to an unintended inability to service outstanding loans. Nevertheless, the evidence from the regressions suggests that loan management in high reform countries has been reasonable while that in low reform countries has been improving, albeit from a very poor base. But it is 
indisputable that banking systems in transition economies have some way to go before they can assure an efficient, flexible and affordable financial intermediation service to their users. Our results indicate that an appropriate policy and regulatory framework may be a necessary condition for significant progress to be made. 


\section{References}

B. Baltagi (1981), "Simultaneous Equations with Error Components", Journal of Econometrics, Vol. 17, pp. 189-200.

B.H. Baltagi (1995), Econometric Analysis of Panel Data, John Wiley \& Sons, Chichester/New York.

E. Berglöf and P. Bolton (2001), "The great divide and beyond - Financial architecture in transition", Journal of Economic Perspectives.

T. Bresnahan (1989), "Empirical studies in industries with market power", in R. Schmalensee and R Willig (eds). Handbook of Industrial Organisation, Volume 2, NorthHolland, Amsterdam.

W. Carlin, S. Fries, M. Schaffer and P. Seabright (2001), "Competition and enterprise performance in transition economies: Evidence from a cross-country survey", EBRD Working Paper No. 63.

O. De Bandt and P. Davis, (2000), Competition, contestability and market structure in European banking sectors on the eve of EMU, Journal of Banking and Finance, vol 24(6), $1045-1066$

X. Freixas and J.-C. Rochet (1998), Microeconomics of Banking, MIT Press, Cambridge, MA.

S. Fries and A. Taci (2001), "Banking reform and development in transition economies", mimeo, EBRD.

J. Gual and D. Neven (1993), "Deregulation of the European banking industry, 1970 1980", European Economy,

C. Hainz (2002), "Bank competition and credit markets in transition economies", University of Munich, mimeo.

G. Kaminsky and C. Reinhart (1999), "The twin crises: Causes of banking and balance of 
payments problems", American Economic Review, Vol., 89, pp. 473 - 500.

A. Marcus (1984), "Deregulation and bank financial policy", Journal of Banking and Finance, Vol. 8, pp. 557-565.

D. Neven and L.-H. Röller (1999), "An aggregate structural model of competition in the European banking industry", International Journal of Industrial Organisation, Vol. 17, pp. $1059-1074$.

C. Ng and P. Seabright (2001), Competition, Privatisation and Productive Efficiency: Evidence from the Airline Industry , Economic Journal, vol 111, 591-619.

S. Ribon and O. Yosha, (1999), Financial liberalisation and competition in banking : an empirical investigation, Tel Aviv Foerder Institute for Economic research and Sackler institute for Economic Research, Working paper 23/99

M. Shubik and R. Levitan (1980), Market Structure and Behavior, Harvard University Press, Cambridge, MA. 
Table 1: Panel estimations of cost function, bank random effects

\section{Pooled sample}

Observations $=1725$

Banks $=478$

Rsq $=0.73$

Variable

Log (loans + deposits $)$

Log wage

Coefficient Std. Err. P-value

$0.643 \quad 0.018 \quad 60.7 \%$

High reform sample

Observations $=833$

Banks $=202$

Rsq $=0.74$

Coefficient Std. Err. P-value
Low reform sample

Observations $=892$

Banks $=276$

Rsq $=0.76$

Coefficient Std. Err. P-value

Loan market share

0.600

$0.023 \quad 0.0 \%$

0.750

$0.028 \quad 0.0 \%$

$\begin{array}{llll}-0.008 & 0.030 & 6.6 \% & 0.097\end{array}$

$0.044 \quad 2.8 \%$

0.038

$0.066 \quad 56.2 \%$

3-firm concentration 0.002

$0.004 \quad 0.7 \%$

0.018

$0.005 \quad 0.0 \%$

0.010

$0.007 \quad 18.3 \%$

ratio

New entrant

$$
-0.201
$$

0.001

$0.1 \%$

0.000

$0.002 \quad 96.4 \%$

0.003

$0.002 \quad 13.8 \%$

Privatised

0.080

$0.084 \quad 36.5 \%$

$-0.384$

$0.098 \quad 0.0 \%$

$-0.071$

$0.133 \quad 59.3 \%$

Foreign majority stake -0.110

$0.076 \quad 6.9 \%$

$-0.015$

$0.086 \quad 86.5 \%$

0.073

$0.137 \quad 59.3 \%$

Log output growth

$-2.960$

$0.067 \quad 24.2 \%$

0.037

$0.074 \quad 61.8 \%$

$-0.225$

$0.125 \quad 7.2 \%$

$0.517 \quad 397.4$

$-4.020$

$0.878 \quad 0.0 \%$

$-2.166$

$0.849 \quad 1.1 \%$

Log inflation

$\begin{array}{lll}-0.112 & 0.099 \quad 30.6 \%\end{array}$

0.182

$0.331 \quad 58.3 \%$

$-0.096$

$0.140 \quad 49.0 \%$

Log real interest rate

0.174

0.083

$1.2 \%$

0.238

$0.254 \quad 34.9 \%$

0.103

$0.116 \quad 37.6 \%$

Time

$0.012 \quad 0.011 \quad 0.9 \%$

0.010

$0.015 \quad 49.4 \%$

0.026

0.024

$28.7 \%$ 
Table 2: Panel estimations of revenue function, bank random effects, split sample

\begin{tabular}{|c|c|c|c|c|c|c|}
\hline \multirow[b]{2}{*}{ Variable } & \multicolumn{3}{|c|}{$\begin{array}{l}\text { High reform sample } \\
\text { Observations }=680 \\
\text { Banks }=201 \\
\text { Rsq }=0.94\end{array}$} & $\begin{array}{l}\text { Low refor } \\
\text { Observatic } \\
\text { Banks }=27 \\
\text { Rsq }=0.93\end{array}$ & $\begin{array}{l}\text { rm sam } \\
\text { ons }=702 \\
4\end{array}$ & ple \\
\hline & Coefficient & Std. Err. & P-value & Coefficient & Std. Err. & P-value \\
\hline Equity & -0.207 & 0.042 & $0.0 \%$ & -0.045 & 0.064 & $47.3 \%$ \\
\hline Deposits & -0.028 & 0.019 & $14.7 \%$ & 0.468 & 0.037 & $0.0 \%$ \\
\hline Loans & 0.191 & 0.022 & $0.0 \%$ & -0.092 & 0.028 & $0.1 \%$ \\
\hline Non-loan assets & 0.117 & 0.015 & $0.0 \%$ & 0.022 & 0.040 & $58.7 \%$ \\
\hline Deposit market share & -0.003 & 0.000 & $0.0 \%$ & & & \\
\hline Loan market share & & & & -0.004 & 0.001 & $0.5 \%$ \\
\hline New entrant & -0.001 & 0.007 & $85.4 \%$ & -0.057 & 0.020 & $0.5 \%$ \\
\hline Privatised & 0.006 & 0.003 & $7.2 \%$ & -0.057 & 0.012 & $0.0 \%$ \\
\hline Foreign majority stake & -0.009 & 0.004 & $0.9 \%$ & -0.128 & 0.034 & $0.0 \%$ \\
\hline Inflation (deposits) & 0.593 & 0.095 & $0.0 \%$ & & & \\
\hline Inflation (loans) & -0.308 & 0.181 & $8.8 \%$ & & & \\
\hline Log real interest rate & -0.031 & 0.037 & $40.5 \%$ & 0.008 & 0.027 & $77.4 \%$ \\
\hline Log output growth & 0.030 & 0.062 & $62.9 \%$ & -0.118 & 0.176 & $50.4 \%$ \\
\hline Year & 0.005 & 0.001 & $0.0 \%$ & -0.052 & 0.005 & $0.0 \%$ \\
\hline & $\chi-s q$ & & p-value & $\chi-s q$ & & $\mathrm{p}$-value \\
\hline D-W-H test deposits & 15.03 & & 0.00 & 0.63 & & 0.43 \\
\hline D-W-H test loans & 105.96 & & 0.00 & 7.29 & & 0.01 \\
\hline D-W-H test mkt share & 26.22 & & 0.00 & 29.30 & & 0.00 \\
\hline
\end{tabular}


Table 3: Panel estimations of revenue function, bank random effects, pooled sample

\author{
Slope Dummies \\ Observations $=1382$ \\ Banks $=475$ \\ Rsq $=0.91$
}

Variable

Coefficient Std. Err. P-value

Transition Interactions

Observations $=684$

Banks $=202$

Rsq $=0.94$

Equity (high reform)

$-0.164$

0.061

$0.7 \%$

Equity (low reform)

$-0.001$

0.042

$99.0 \%$

Equity

Equity*Bank Reform

Deposits (high reform)

0.056

$0.022 \quad 1.2 \%$

Deposits (low reform)

0.397

0.021

$0.0 \%$

Deposits

Deposits*Bank Reform

Loans (high reform)

0.137

0.017

$0.0 \%$

Loans (low reform)

$-0.082$

0.021

$0.0 \%$

Loans

Loans*Enterprise

Reform

Non-loan assets

0.089

0.020

$0.0 \%$

$\begin{array}{lll}0.953 & 0.254 & 0.0 \%\end{array}$

$-0.252$

0.084

$0.3 \%$

Determinants of margins:

\begin{tabular}{|c|c|c|c|c|c|c|}
\hline Loan market share & -0.001 & 0.000 & $0.1 \%$ & -0.004 & 0.000 & $0.0 \%$ \\
\hline New entrant & -0.020 & 0.010 & $4.1 \%$ & -0.044 & 0.012 & $0.0 \%$ \\
\hline Privatised & -0.001 & 0.004 & $75.2 \%$ & -0.014 & 0.004 & $0.2 \%$ \\
\hline Foreign majority stake & 0.002 & 0.005 & $59.3 \%$ & -0.002 & 0.005 & $70.9 \%$ \\
\hline Log real interest rate & 0.039 & 0.018 & $2.6 \%$ & 0.091 & 0.018 & $0.0 \%$ \\
\hline Log output growth & -0.226 & 0.068 & $0.1 \%$ & -0.762 & 0.056 & $0.0 \%$ \\
\hline Inflation & & & & -0.179 & 0.035 & $0.0 \%$ \\
\hline \multirow[t]{2}{*}{ Year } & -0.004 & 0.001 & $0.0 \%$ & & & \\
\hline & $\chi$-sq & & $\mathrm{p}$-val & $\chi$-sq & & $\mathrm{p}$-value \\
\hline \multirow[t]{2}{*}{ D-W-H test deposits } & $\begin{array}{l}5.47 \\
\text { (hi ref) }\end{array}$ & & 0.02 & 21.68 & & 0.00 \\
\hline & $\begin{array}{l}36.61 \\
\text { (lo ref) }\end{array}$ & & 0.00 & & & \\
\hline \multirow[t]{2}{*}{ D-W-H test loans } & $\begin{array}{l}3.55 \\
\text { (hi ref) }\end{array}$ & & 0.06 & 140.31 & & 0.00 \\
\hline & $\begin{array}{l}70.17 \\
\text { (lo ref) }\end{array}$ & & 0.00 & & & \\
\hline D-W-H test mkt share & 0.01 & & 0.91 & 10.58 & & 0.00 \\
\hline
\end{tabular}




\begin{tabular}{|c|c|c|c|c|c|c|c|}
\hline Year & 1994 & 1995 & 1996 & 1997 & 1998 & 1999 & Average \\
\hline $\begin{array}{l}\text { Low } \\
\text { reform }\end{array}$ & $5.7 \%$ & $6.3 \%$ & $8.7 \%$ & $5.3 \%$ & $4.4 \%$ & $4.0 \%$ & $6.0 \%$ \\
\hline $\begin{array}{l}\text { High } \\
\text { reform }\end{array}$ & $4.4 \%$ & $4.3 \%$ & $3.9 \%$ & $3.7 \%$ & $3.7 \%$ & $3.5 \%$ & $3.9 \%$ \\
\hline Average & $4.8 \%$ & $5.1 \%$ & $5.8 \%$ & $4.3 \%$ & $3.9 \%$ & $3.6 \%$ & $3.6 \%$ \\
\hline
\end{tabular}


Chart 1: Real loan growth versus bank capital in high reform states

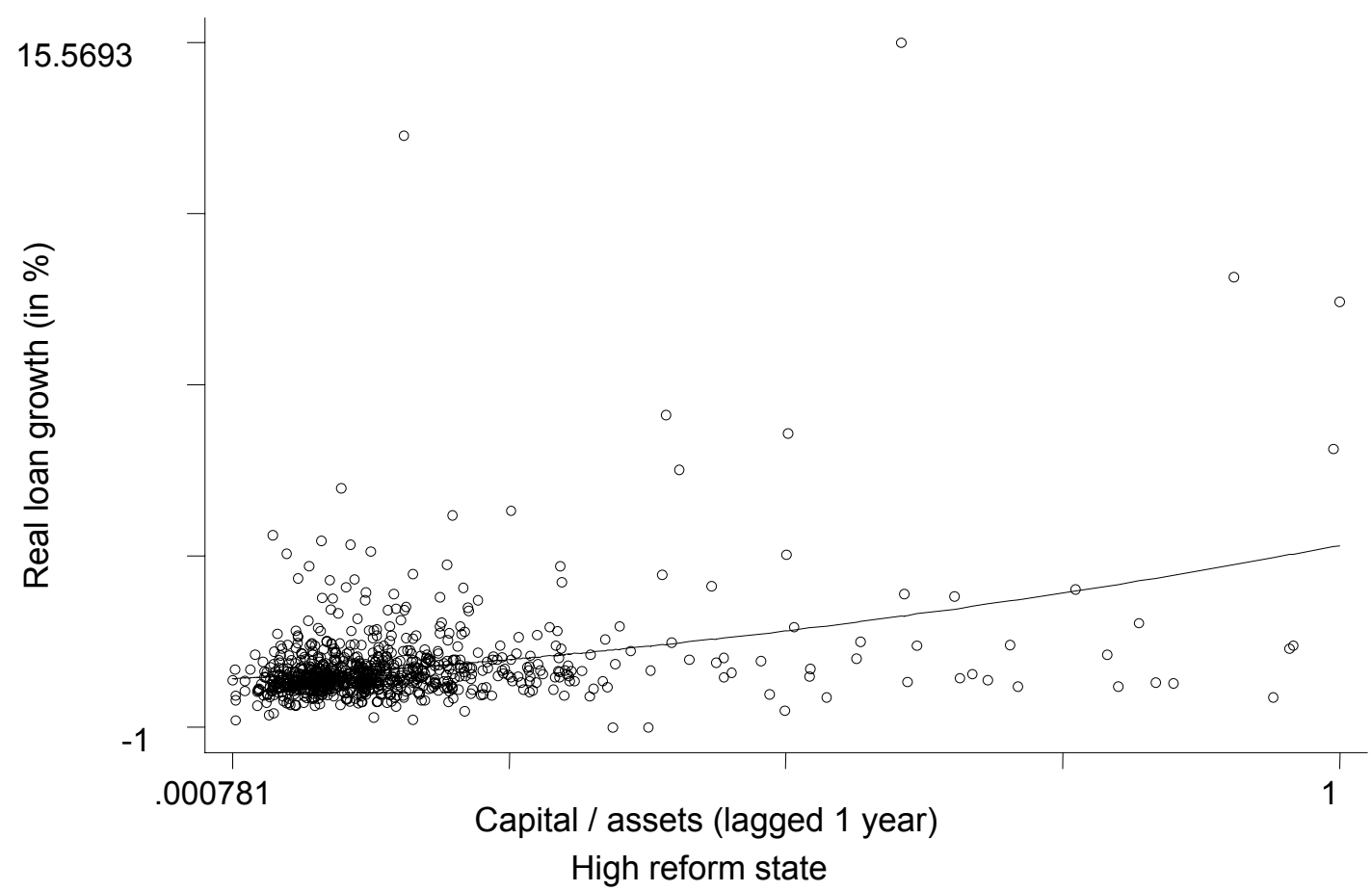

Chart 2: Real loan growth versus bank capital in low reform states

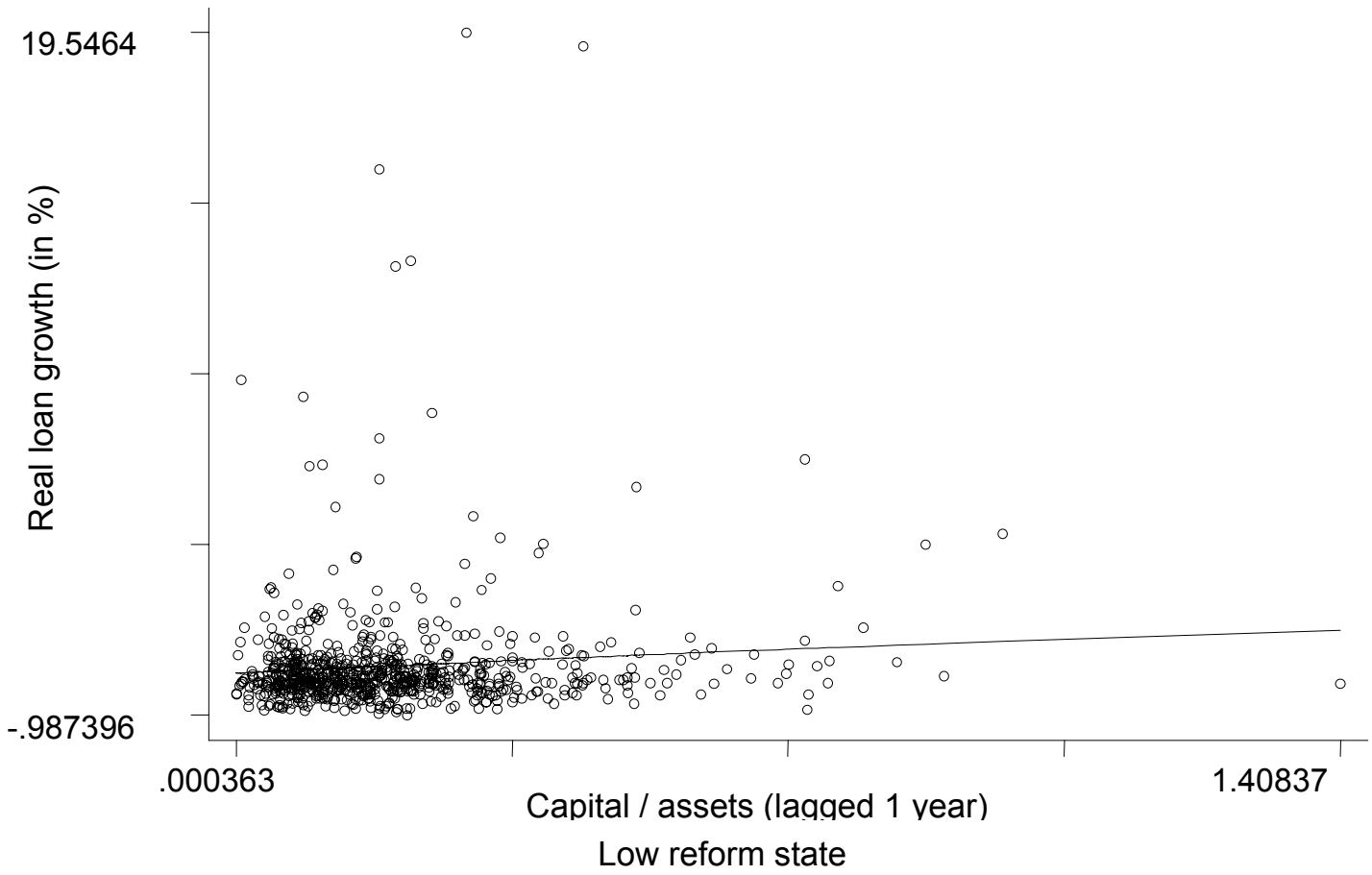




\section{Chart 3: Density functions for bank profitability in high and low reform states}

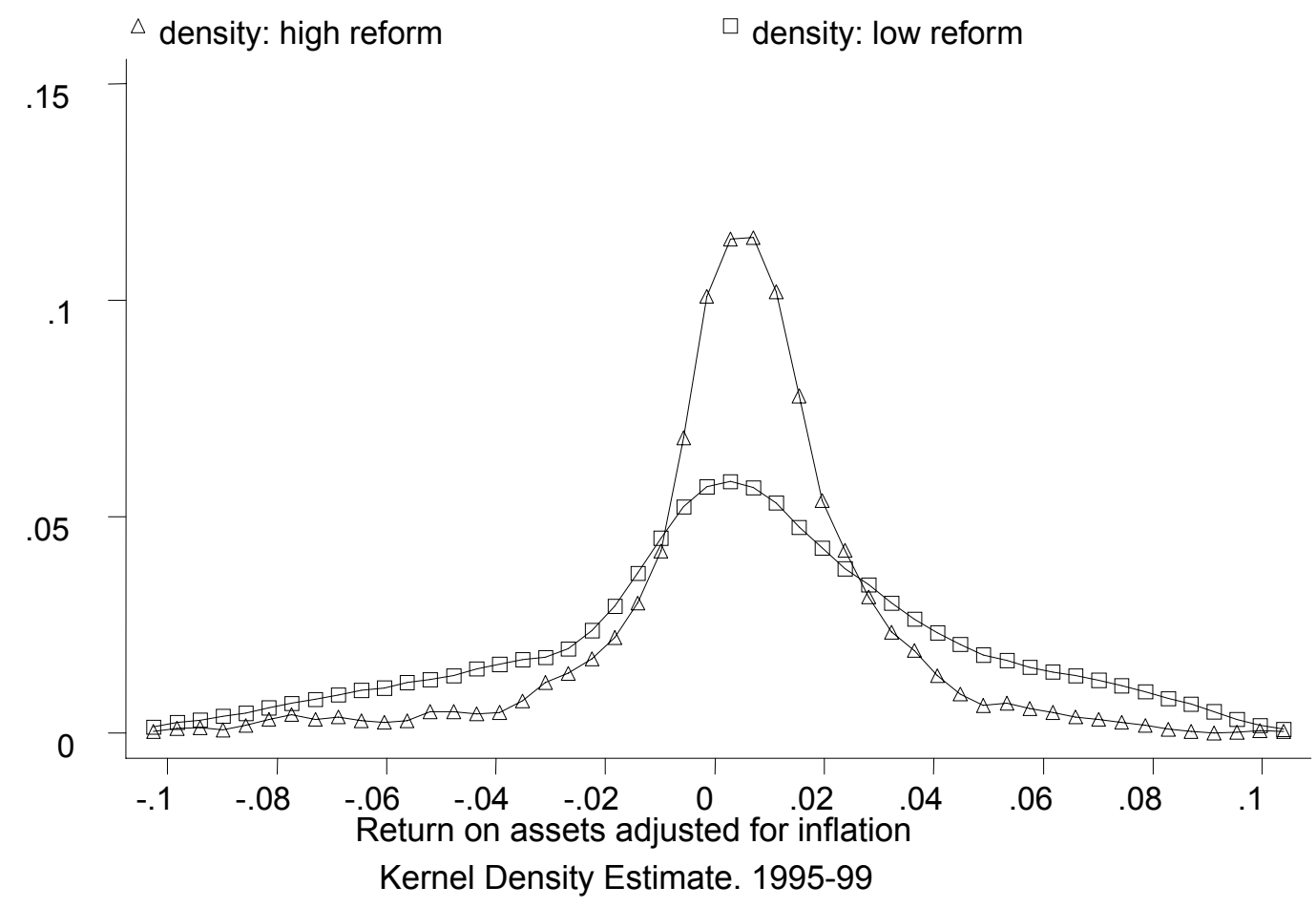

Chart 4: Density function for bank profitability in high reform states by year

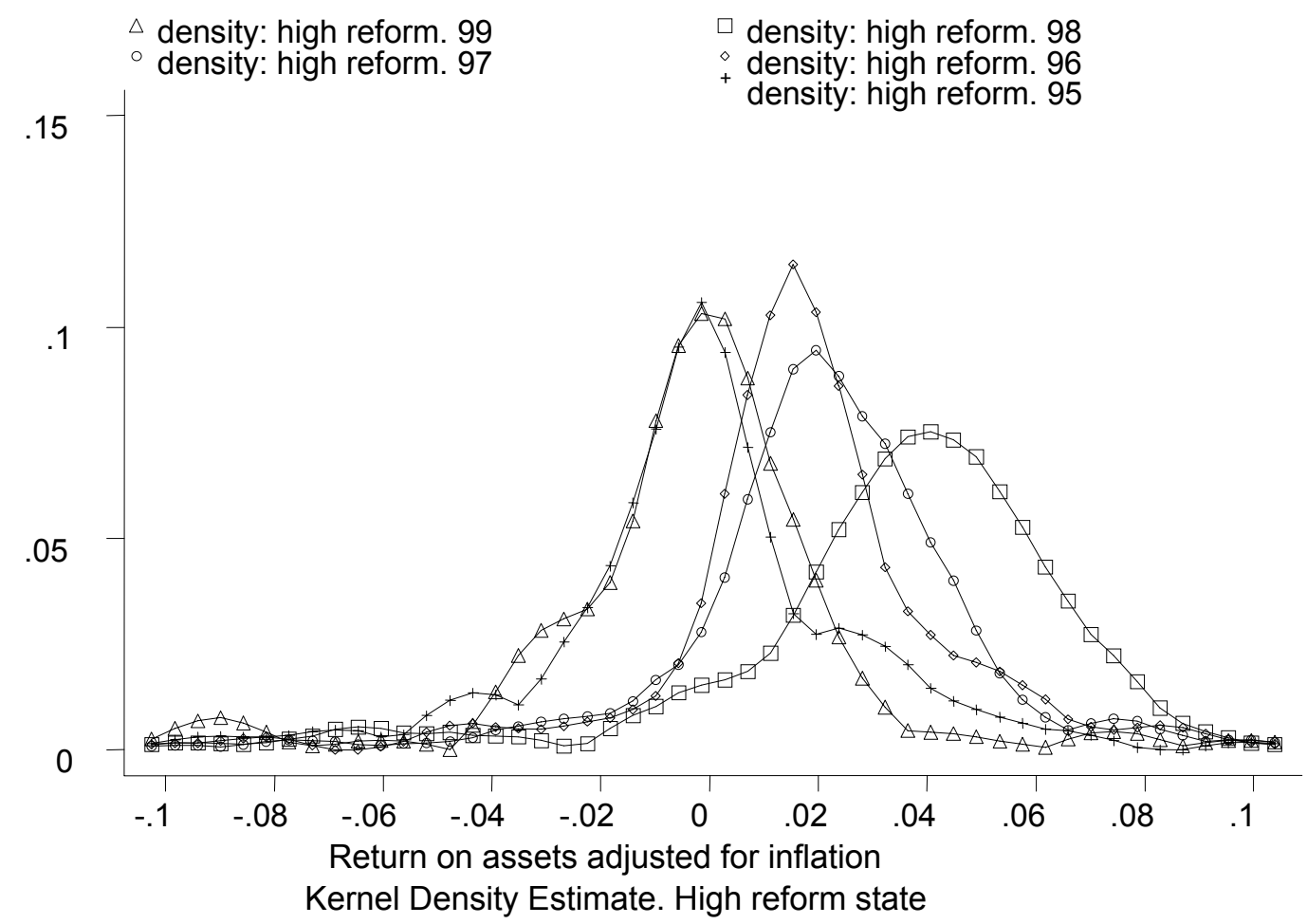


Chart 5: Density function for bank profitability in low reform states by year

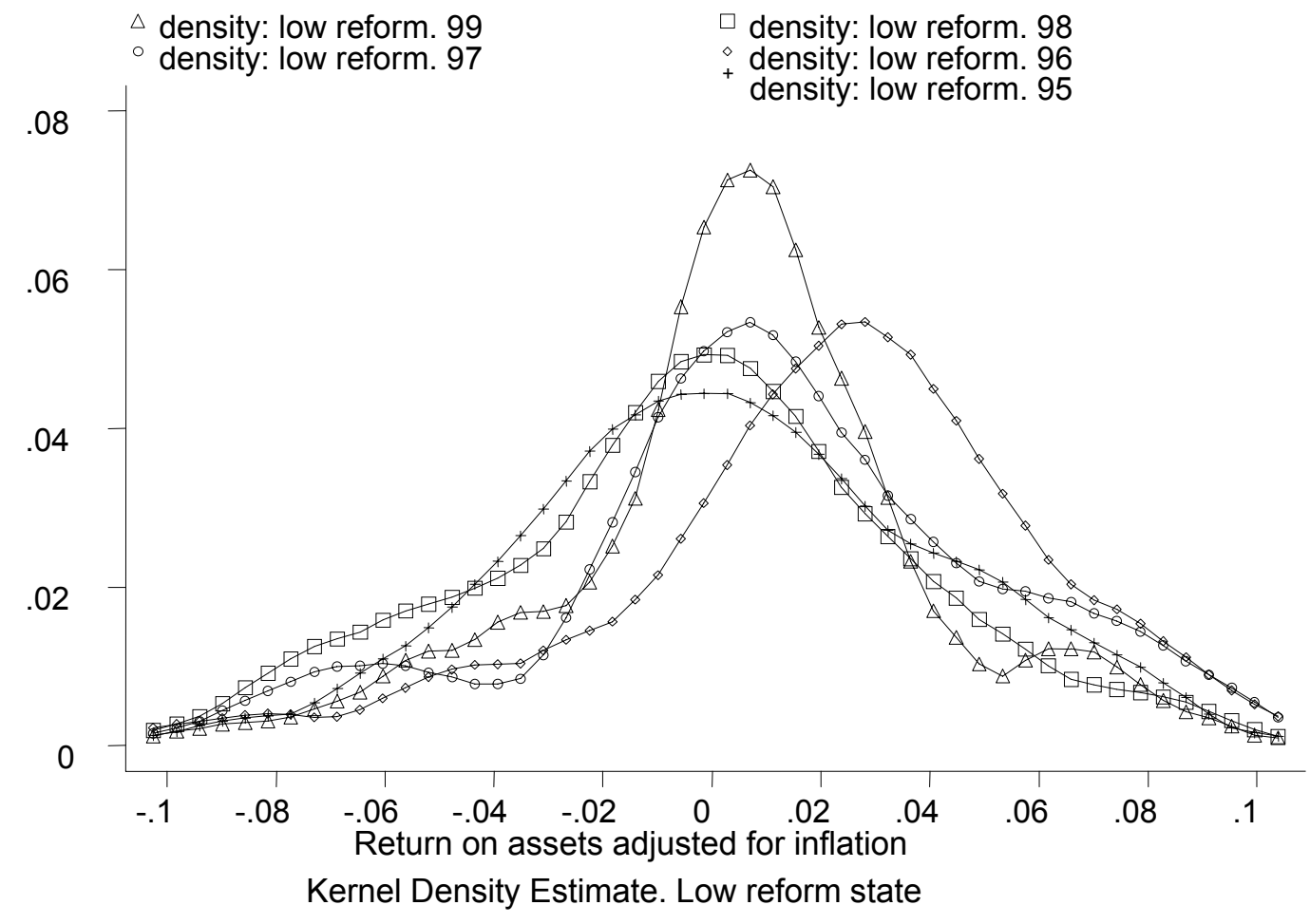

